\title{
Powder microscopic, physicochemical and chromatographic approach for the quality control of anti-hypertensive drug Rattha Piththathirku Kudinir Chooranam
}

\author{
Achintya Kumar Mandal ${ }^{1}$, Sujith Thatipelli ${ }^{1}$, Rajesh Allu ${ }^{1}$, Divya Kallingil Gopi ${ }^{2}$, Sunil Kumar Koppala \\ Narayana $^{2} \&$ Shakila Ramachandran ${ }^{1 *}$ \\ ${ }^{1}$ Department of Chemistry, ${ }^{2}$ Department of Pharmacognosy, Siddha Central Research Institute (Central Council for Research in Siddha, \\ Ministry of AYUSH, Government of India), Anna Hospital Campus, Arumbakkam, Chennai 600 106, Tamil Nadu, India \\ *Email: r.shakila@gov.in
}

\section{ARTICLE HISTORY}

Received: 16 February 2021

Accepted: 24 April 2021

Available online: 01 July 2021

\section{KEYWORDS}

Caranai; Cukku; Hypertension;

Purpura; Zaleya decandra;

Zingiber officinale.

\section{ABSTRACT}

The present work aims to study powder microscopy, physicochemical and high-performance thin-layer chromatography photo documentation and fingerprint profiles of a Siddha drug, Rattha Piththathirku Kudinir Chooranam (RPK). The raw drugs were collected, authenticated and the RPK was prepared. Then the drug was investigated for powder microscopic characters, physicochemical parameters, Thin Layer Chromatographic photo documentation (TLC), High-Performance Thin-Layer Chromatographic (HPTLC) fingerprint profiles of successive $n$-hexane, successive chloroform, successive ethanol and hydro alcohol (1:1) extracts. The successive and hydro alcohol extracts of the drug displayed distinct TLC spots and HPTLC peaks which are distinct to this drug.

\section{Introduction}

Hypertension is a major health issue that leads to an increase in the risks of heart, brain, kidney and other organ related diseases. It is one of the major reasons for early death of public (1). According to the World Health Organization, it is estimated that 1.13 billion people are suffering from hypertension worldwide, and two-thirds of them belong to low and middle income countries (2). Traditional and complementary medicine plays an important role in maintaining good health due to its easy acceptance by the human body (3) and lesser side effects. Among 170 Member States of WHO, 88\% recognised their use of traditional and complementary medicine (4). Rattha Pitthathirku Kudinir (RPK) is a Siddha drug consisting of cukku [Zingiber officinale Linn. (rhizome)] and caranai [Zaleya decandra (L.) Burm. (root)]. Ratthapitham refers to Purpura i.e. hypertension. According to Siddha literature, 30 to $60 \mathrm{ml}$ of medicine has to be taken twice daily for treating hypertension (5).

The plant Zaleya decandra is commonly called Purslane (English) and belongs to Aizoaceae (6). It is native to India, Sri Lanka and Australia and introduced to tropical regions of Africa and South America $(7,8)$. Traditionally the root is used for the treatment of hepatitis, asthma and orchitis (9). Decoction of root bark is well known as an aperient
(10). The preliminary qualitative phytochemical screening has been reported (6) to show alkaloids, carbohydrates, phenols, terpenoids, cardiac glycosides, fatty acids, saponins, tannins and proteins. GC-MS analysis of $Z$. decandra revealed that momeinositol (26.57\%), methyl ester of 2-hydroxyvaleric acid (18.9\%), 2-methyl-hexanoic acid, (7.74\%), 2-amino-5-(2-carboxy)vinyl) imidazole, (7.71\%), decanoic acid (7.45\%), allantoic acid (6.90\%) are present in major concentrations; whereas dl-citrulline (3.8\%), benz(e)azulene-3,8-dione, octanoic acid (2.16\%), 1,3-dioxolan-4-one, strogogenin (1.04\%), 12,15-octadecatrienoic acid, $n$-hexadecanoic acid (0.89\%), 1H-pyrazole, 4,5-dihydro-3-methyl- $(0.66 \%)$, E11-tetradecenol, trimethylsilyl ether $(0.59 \%)$ and malonic acid were reported to be present in minimal concentrations (7). Oleic acid has been isolated from the root of $Z$. decandra (11). Pharmacologically it shows antidiabetic (12), hepatoprotective, antioxidant (13), cytotoxic activity (7) and anthelmintic activity (6).

Zingiber oficinale is used in several ancient systems of medicines for the treatment of catarrh, rheumatism, nervous diseases, gingivitis, toothache, asthma, stroke, diabetes, headache, gastrointestinal discomforts, nausea, vomiting and the common cold (14-16). Traditionally ginger is being administered for hypertensive patients since ancient days (17). It consists of volatile oils, gingerol, diarylheptanoids, proteins, amino acids, sugar,

(c) Mandal et al (2021). This is an open-access article distributed under the terms of the Creative Commons Attribution License, which permits unrestricted use, distribution and reproduction in any medium, provided the original author and source are credited (https://creativecommons.org/licenses/by/4.0/). 
organic acids and inorganic elements. It comprises more than 300 types of compounds, mainly categorised into 3 different types: 194 types of volatile oil compounds, 85 types of gingerols and 28 types of diarylheptanoids (18). The major phytoconstituents of Z. officinale are 6-shogaol, 6-gingerol, 8-gingerol, 10gingerol, zingiberol, $\beta$-phellandrene, $\alpha$-zingiberene, arcurcumene and $\beta$-bisabolene along with the compounds gingerdiols, $\alpha$-santalol, $\beta$-eudesmol, nerolidol, farnesol, elemol, neral, geranial, $\alpha$ and $\beta$ pinene, camphene, sabinene, myrecene and limonene (18-24). Pharmacological actions of ginger are antidiabetic, anti-inflammatory, analgesic, antimicrobial, tissue and radio-protective, anti-emetic, antitumorigenic and antioxidant effects (25). The hypertensive effect and antiplatelet effect of $Z$. officinale have been well registered. The study of fresh ginger in anaesthetised rats exhibited a blood pressure lowering effect, possibly through a specific blockade of the voltage-dependent $\mathrm{Ca}^{2+}$ channels (26). The study of $Z$. officinale on the pharmacodynamic and pharmacokinetic of losartan in hypertensive rats divulged the hypertension management effect of it (27).

As hypertension is a common illness, and there are medications available in several brand names; thus quality control parameters are required for the analysis of commercial samples. Hence, it is decided to evaluate the powder microscopic, physicochemical values, document thin layer photography and record the HPTLC fingerprint profiles.

\section{Materials and Methods}

\section{Plant material}

Zaleya decandra root and Zingiber oficinale rhizome were collected from the Survey of Medicinal Plants Garden, Mettur, Tamil Nadu and were authenticated by referring floras and chemical test.

\section{Formulation of RPK}

The rhizome of Zingiber officinale and the roots of Zaleya decandra were washed well in running water and then shade dried. The dried samples were powdered and passed through a sieve no. 60. The powdered drugs were mixed thoroughly in the ratio of 1:1 (5).

\section{Powder Microscopy}

A pinch of the mixed powdered sample was mounted on a microscopic slide with a drop of $50 \%$ glycerol after treating it with $0.1 \%$ chloral hydrate solution. Characters were observed using Nikon ECLIPSE E200 trinocular microscope attached with Zeiss ERc5s digital camera under bright field light. Photomicrographs of diagnostic characters were captured and documented (28).

\section{Physico-chemical Analysis}

All the physicochemical parameters were evaluated according to the standard methods (28).

\section{Chemicals, Solvents and Instruments}

Analytical grade solvents $n$-hexane, toluene, chloroform, ethyl acetate, ethanol, methanol and formic acid were purchased from Merck. Vanillin (1 gm) sulphuric acid in methanol (5\%) solution (VSR) was used for visualisation. For HPTLC, Autosampler ATS4, twin trough chambers, visualiser, scanner 4 (Scanner_210441) linked with WINCATS software, plate heater (all from CAMAG, Switzerland) were used.

\section{Extract Preparation}

RPK (4 gm) was subjected to successive extraction with $100 \mathrm{ml}$ of each of $n$-hexane, chloroform and ethanol using Soxhlet apparatus. Extracts were concentrated to dryness. The total residues were resolvated with the corresponding solvents and made up to $10 \mathrm{ml}$, and transferred into sample vials for TLC application. For hydro alcohol extract, $1 \mathrm{gm}$ of the drug was refluxed with $25 \mathrm{ml}$ of aqueous ethanol (1:1 ratio) for 2 hrs, cooled, filtered and used for TLC in the sample vial.

\section{HPTLC analysis}

Successive $n$-hexane, chloroform and ethanol extract, $10 \mu \mathrm{l}$ each, were applied on three different silica gel $60 \mathrm{~F}_{254}$ pre-coated aluminium plate $(6 \times 10 \mathrm{~cm})$ as 8 $\mathrm{mm}$ band $10 \mathrm{~mm}$ from the bottom. The plate containing $n$-hexane extract was developed using toluene: ethyl acetate: formic acid (8: 2: $0.5, v / v / v$ ), chloroform extract plate using toluene: ethyl acetate: formic acid (6.0:4.0:1.0, $v / v / v)$ and ethanol extract by using toluene: ethyl acetate : methanol: formic acid (3.0:4.0:3.0: $0.5, v / v / v / v)$ separately in pre-saturated twin trough chamber $(10 \times 10 \mathrm{~cm})$. The developed plates were dried, and photographs were taken under UV, followed by scanning under $\lambda 254$ (absorbance mode, $D_{2}$ lamp) and $\lambda 366$ (fluorescence mode, $\mathrm{Hg}$ lamp) respectively with a slit dimension $6 \times$ $0.45 \mathrm{~mm}$ and scanning speed of $20 \mathrm{~mm} / \mathrm{s}$. The scanned plates were dipped in VSR and heated at $105^{\circ} \mathrm{C}$ till the appearance of coloured bands. Photographs were taken immediately at white light, followed by scanning at $\lambda 520$ (absorption mode, W lamp).

\section{Results and Discussion}

\section{Powder Microscopy}

The powder microscopic observation showed the following characters, Zingiber officinale: suberised cork; scalariform and pitted vessels; septate non lignified fibre; oleoresin and sac shaped starch grains; Zaleya decandra: thick-walled cork cells, fibrous layers, crystal fibres, pitted vessels, spiral vessels and heterogenous prismatic crystals (Fig. 1). The powder is pale yellow with a characteristic odour and taste.

Microscopic examination of the powdered compounded formulation revealed suberised cork, oleoresin and sac shaped starch grains which form the diagnostic characteristics of Zingiber officinale rhizome and thick-walled cork cells, crystal fibres together with heterogenous prismatic crystals could be attributed to Zaleya decandra root. Each species has its own diagnostic character, which can be used to confirm its identity. In the present study, the powder microscopic characterisation of the compound 


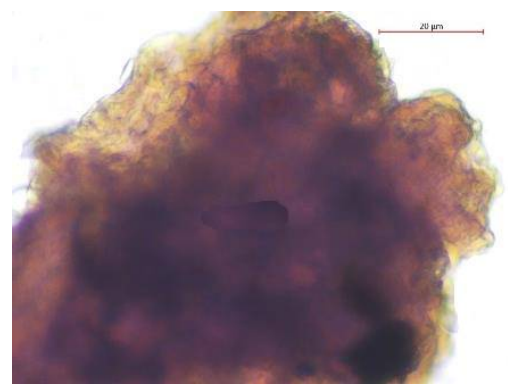

Suberised cork of Z. officinale

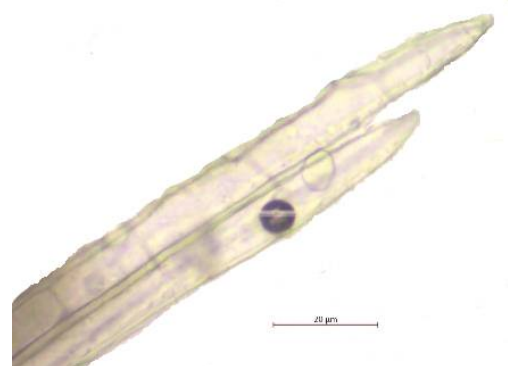

Septate non lignified fibre of $Z$. officinale

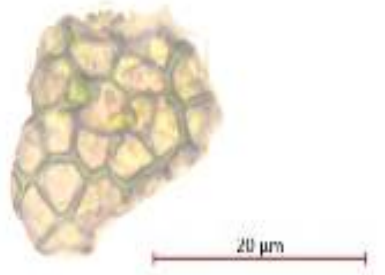

Cork cells of $Z$. decandra

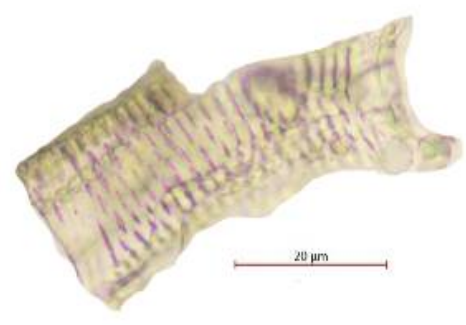

Pitted vessel of $Z$. decandra

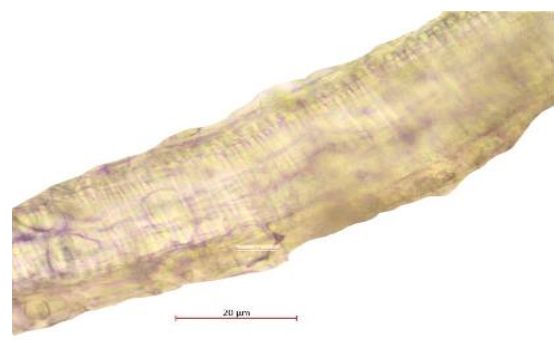

Scalariform vessels of $Z$. officinale

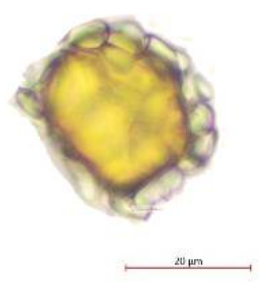

Oleoresin of Z. officinale

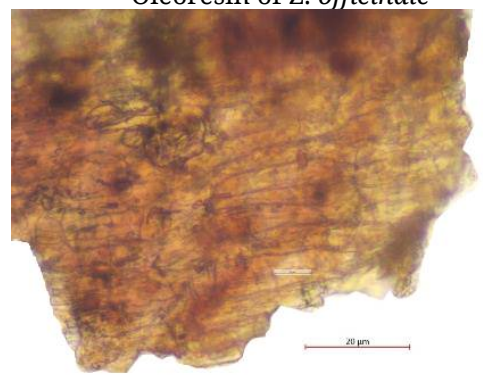

Fibrous layer of $Z$. decandra

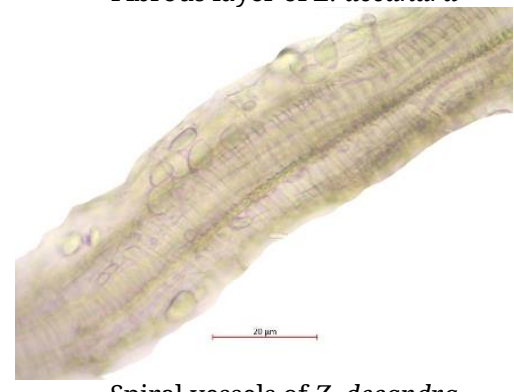

Spiral vessels of $Z$. decandra

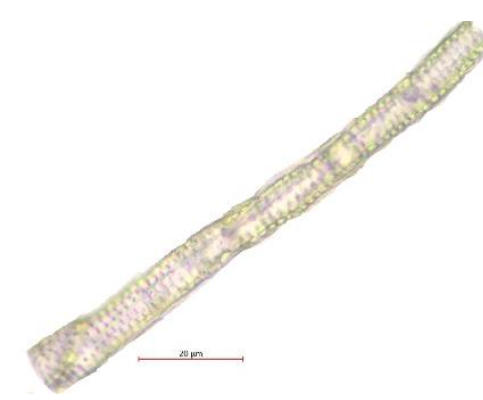

Pitted vessel of Z. officinale

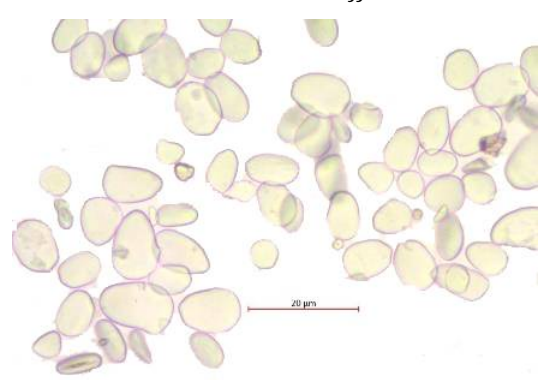

Starch grains of Z. officinale

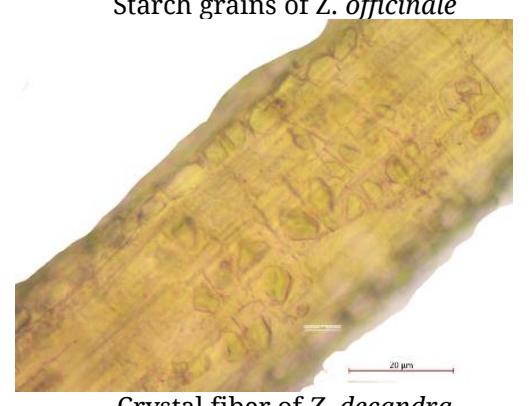

Crystal fiber of $Z$. decandra

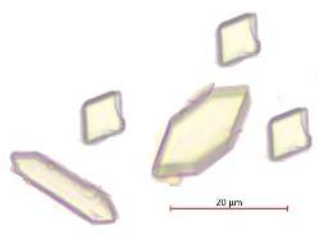

Prismatic crystals of Z. decandra

Fig. 1. Powder Microscopy of Rattha Piththathirku Kudinir Chooranam.

formulation has led to the effective diagnosis of the individual herbal drugs used in it.

\section{Physicochemical results}

The physicochemical values of the tested drug are presented in Table 1. Drug quality is markedly affected by moisture content denoted by loss on drying (LOD), which alters the shelf life of herbal drug. LOD value was found to be $10.38 \pm 0.17 \%$. Total ash value was determined as $6.87 \pm 0.09 \%$. Total ash contains physiological and non-physiological inorganic salts of phosphates, silicates and carbonates. Acid insoluble ash (AIA) value represents the amount of earthing matters present in roots and rhizomes. AIA was found to be $1.43 \pm 0.09 \%$. The alcoholic soluble extractive value was estimated as 17 $\pm 0.15 \%$, whereas the water-soluble extractive value was $12.26 \pm 0.16 \%$. The $\mathrm{pH}$ of the drug was determined as 4.62 , which revealed the acidic nature of the drug. The physicochemical values of any herbal drug would vary and the same could be considered for the quality control of drugs (29-31).

\section{TLC Photo documentation}

In the TLC photo documentation of $n$-hexane extract of RPK (Supplementary Fig. 1), 8 bands were visualized with $\mathrm{R}_{\mathrm{f}} 0.11,0.25,0.28,0.33,0.41,0.52$, 0.67 and 0.73 (all green) under short UV; 8 bands

Table 1. Physicochemical values of Rattha Piththathirku Kudinir Chooranam

\begin{tabular}{ll}
\hline Parameters & $\begin{array}{c}\text { Mean } \pm \text { SD } \\
(\mathbf{n}=\mathbf{2})\end{array}$ \\
\hline Loss on drying $\left(105^{\circ} \mathrm{C}\right)(\%)$ & $10.38 \pm 0.17$ \\
\hline Total ash (\%) & $6.87 \pm 0.09$ \\
\hline Acid insoluble ash (\%) & $1.43 \pm 0.09$ \\
\hline Water-soluble extract (\%) & $12.26 \pm 0.16$ \\
\hline Alcohol soluble extract (\%) & $5.17 \pm 0.15$ \\
\hline pH (10 \% solution) & $4.62 \pm 0.01$ \\
\hline
\end{tabular}


were visualized with $\mathrm{R}_{\mathrm{f}} 0.08$ (blue), 0.12 (green), 0.18 (blue), 0.25 (green), 0.34 (red), 0.50 (violet), 0.58 (blue) and 0.77 (blue) under long UV and 10 bands were visualized with $\mathrm{R}_{\mathrm{f}} 0.04$ (violet), 0.10 (violet), 0.24 (violet), 0.28 (violet), 0.34 (red), 0.45, 0.69 and 0.77 (all violet).

The photo documentation of successive chloroform extract (Supplementary Fig. 2) revealed 6 bands with $\mathrm{R}_{\mathrm{f}} 0.03,0.42,0.48,0.54,0.60$ and 0.76 (all green) under short UV; 6 bands with $\mathrm{R}_{\mathrm{f}}$ 0.05, $0.23,0.40,0.44,0.54$ (all blue) and 0.72 (fluorescent blue) under long UV and 7 bands with 0.03 (brown), $0.23,0.25,0.42,0.52,0.63$ and 0.83 (all violet) under white light post derivatization.

In the successive ethanol extract of RPK (Supplementary Fig. 3), 7 bands with $\mathrm{R}_{\mathrm{f}}$ 0.04, 0.09, $0.20,0.28,0.47,0.67$ and 0.77 (all green) under short UV; 9 bands with $\mathrm{R}_{\mathrm{f}}$ 0.04,0.09, 0.21,0.24, 0.31, 0.45, $0.53,0.66$ and 0.82 (all blue) under long UV and 6 bands for post derivatized plate under white light with $0.05,0.11,0.47$ (brown), 0.66, 0.72, 0.79 (violet) were observed.

TLC photo documentation of hydro-alcohol extract of RPK (Supplementary Fig. 4) showed 5 bands with $R_{f} 0.09,0.14,0.52,0.66$ and 0.70 (all green) under short UV; 5 bands under long UV with $\mathrm{R}_{\mathrm{f}} 0.16$ (blue), 0.59 (blue), 0.66 (blue), 0.67 (light green) and 0.82 (blue) and 6 bands with $\mathrm{R}_{\mathrm{f}} 0.06$ (black), 0.12 (black), 0.29 (black), 0.52 (green), 0.67 (violet) and 0.70 (violet) under white light post derivatization.

\section{HPTLC Densitometry}

Scanning of plate developed using $n$-hexane extract of RPK (Supplementary Fig. 1) divulged 13 peaks with $\mathrm{R}_{\mathrm{f}} 0.11$ (area 10.88\%), 0.19 (1.96\%), 0.25 (13.64\%), 0.28 (8.00\%), 0.33 (6.45\%), 0.41 (5.06\%), 0.52 (11.32\%), 0.59 (6.64\%), 0.67 (11.84\%), 0.73 (19.92\%), 0.87 (1.67\%), 0.89 (2.16\%) and $0.97(0.46 \%)$ under short UV; 12 peaks under long UV with $\mathrm{R}_{\mathrm{f}} 0.08$ (3.84\%), 10 (1.89\%), 0.12 (2.28\%), 0.14 (1.85\%), 0.18 (4.00\%), 0.25 (22.78\%), 0.34 (48.84\%), 0.50 (1.56\%), 0.58 (9.86\%), $0.77(0.56 \%), 0.83(0.16 \%)$ and 0.93 (2.39\%) and 12 peaks with $\mathrm{R}_{\mathrm{f}} 0.04$ (1.29\%), 0.10 (12.62\%), 0.24 (8.59\%), 0.28 (4.99\%), $0.34(10.13 \%)$, 0.45 (13.00\%), 0.53 (7.33\%), 0.69 (16.47\%), 0.77 (24.88\%), 0.91 (0.21\%), $0.96(0.25 \%)$ and $0.98(0.23 \%)$ under white light post derivatization.

For successive chloroform extract (Supplementary Fig. 2) 9 peaks were detected with $\mathrm{R}_{\mathrm{f}} 0.01$ (1.08\%), 0.03 (1.51\%), 0.20 (0.26\%), 0.42 (27.34\%), 0.48 (10.30\%), 0.53 (13.29\%), 0.60 (26.21\%), $0.76(19.40 \%)$ and $0.94(0.62 \%)$ under short UV; 10 peaks with $\mathrm{R}_{\mathrm{f}} 0.06(1.18 \%), 0.23$ (1.30\%), 0.28 (1.06\%), 0.40 (7.03\%), 0.44 (4.56\%), 0.49 (2.86\%), 0.54 (5.74\%), 0.71 (74.39\%), $0.80(1.42 \%), 0.86(0.45 \%)$ under long UV and 13 bands with $\mathrm{R}_{\mathrm{f}} 0.01(0.76 \%)$, 0.03 (0.80\%), 0.06 (0.13\%), $0.15(0.24 \%), 0.23(3.77 \%)$, 0.25 (1.92\%), 0.35 (10.91\%), 0.42 (16.23\%), 0.46 (6.09\%), 0.52 (13.84\%), 0.63 (23.29\%), 0.83 (20.68\%) and $0.93 \quad(1.36 \%)$ under white light post derivatization.

Successive ethanol extract (Supplementary Fig. 3) showed 8 peaks with $R_{f} 0.04$ (0.14\%), 0.09 (1.02\%),

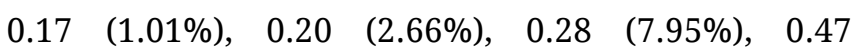
(26.62\%), 0.67 (41.41\%) and 0.76 (19.19\%) under short UV; 13 peaks with $\mathrm{R}_{\mathrm{f}} 0.01$ (1.70\%), 0.04 (2.08\%), 0.09 (0.39\%), 0.13 (0.59\%), 0.21 (3.61\%), 0.24 (1.98\%),

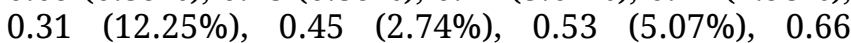
(53.74\%), 0.82 (14.37\%), $0.95 \quad(0.95 \%)$ and 0.97 $(0.55 \%)$ under long UV and 9 peaks with $\mathrm{R}_{\mathrm{f}} 0.01$ (3.83\%), 0.05 (9.72\%), 0.11 (20.84\%), $0.26(0.46 \%)$, 0.47 (9.43\%), 0.66 (22.30\%), 0.72 (6.39\%), 0.79 $(17.15 \%)$ and $0.89(9.88 \%)$ in white light post derivatization.

Scanning of hydro-alcohol extract (Supplementary Fig. 4) of revealed 11 peaks with $\mathrm{R}_{\mathrm{f}}$ 0.01 (area 13.59\%), 0.09 (2.54\%), $0.14(0.48 \%), 0.17$ (0.95\%), 0.24 (3.96\%), 0.26 (6.23\%), 0.34 (0.71\%), 0.52 $(22.87 \%), \quad 0.66 \quad(31.70 \%), 0.70 \quad(13.75 \%)$ and 0.79 $(3.22 \%)$ under short UV; 11 peaks with $\mathrm{R}_{\mathrm{f}} 0.02$ (area $48.05 \%), 0.08$ (3.30\%), 0.11 (1.18\%), 0.16 (11.53\%), 0.20 (1.26\%), 0.59 (8.85\%), 0.66 (9.52\%), 0.67 (9.80\%), $0.82(5.63 \%), 0.96(0.35 \%)$ and $0.97(0.51 \%)$ under long UV and 12 peaks with $\mathrm{R}_{\mathrm{f}} 0.01$ (area 6.28\%), 0.06 (10.88\%), 0.12 (22.52\%), 0.29 (6.39\%), 0.34 (3.18\%), 0.52 (13.57\%), 0.67 (20.84\%), 0.70 (11.70\%), 0.79 (2.89), 0.87 (0.45), 0.88 (0.93) and 0.95 (0.38\%) under white light post derivatization.

Scanning of $n$-hexane extract of RPK revealed major peaks at $\mathrm{R}_{\mathrm{f}} 0.73$ (area 19.92\%), 0.25 (13.64\%) and 0.67 (11.84\%) under short UV; at $\mathrm{R}_{\mathrm{f}} 0.34$ (area 48.84\%), 0.25(22.78\%) and $0.58(9.76 \%)$ under long $\mathrm{UV}$; and peaks at $\mathrm{R}_{\mathrm{f}} 0.77$ (area $\left.24.88 \%\right), 0.69$ (16.47\%) and $0.45(13.00 \%)$ under white light scanning of post derivatized plate. Scanning of successive chloroform extract revealed prominent peaks $\mathrm{R}_{\mathrm{f}} 0.42$ (area $27.34 \%), \mathrm{R}_{\mathrm{f}} 0.60(26.21 \%)$ and $\mathrm{R}_{\mathrm{f}} 0.76$ (19.40\%) under short UV; peaks $\mathrm{R}_{\mathrm{f}} 0.71$ (area $\left.74.39 \%\right), \mathrm{R}_{\mathrm{f}} 0.40(7.03 \%)$ and $0.44(4.56 \%)$ under long UV and peaks $R_{f} 0.63$ (area 23.29\%), $\mathrm{R}_{\mathrm{f}} 0.83(20.68 \%)$ and $\mathrm{R}_{\mathrm{f}} 0.42$ (16.23\%) under white light of post derivatized plate. Finger print profile of successive ethanol extract exposed major peaks $\mathrm{R}_{\mathrm{f}} 0.67$ (area 41.41\%), $\mathrm{R}_{\mathrm{f}} 0.47$ (26.62\%) and $\mathrm{R}_{\mathrm{f}} 0.76(19.19 \%)$ under short UV, peaks $\mathrm{R}_{\mathrm{f}} 0.66$ (area 53.74\%), $\mathrm{R}_{\mathrm{f}} 0.82(14.37 \%)$ and $\mathrm{R}_{\mathrm{f}} 0.31(12.25 \%)$ under long UV and peaks $\mathrm{R}_{\mathrm{f}} 0.66$ (22.30\%), $\mathrm{R}_{\mathrm{f}}$ $0.11(20.84 \%)$ and $R_{f} 0.79(17.15 \%)$ under white light of post derivatized plate.

Densitometric scan of hydro-alcohol extract of RPK divulged paramount peaks $R_{f} 0.66$ (area $31.70 \%), \mathrm{R}_{\mathrm{f}} 0.52(22.87 \%)$ and $\mathrm{R}_{\mathrm{f}} 0.70(13.75 \%)$ under short UV, peaks $\mathrm{R}_{\mathrm{f}} 0.02$ (48.05\%), $\mathrm{R}_{\mathrm{f}} 0.16$ (11.53\%) and $\mathrm{R}_{\mathrm{f}}$ 0.66(9.52\%) under long UV and peaks $\mathrm{R}_{\mathrm{f}} 0.12$ (area $22.52 \%), \mathrm{R}_{\mathrm{f}} 0.67(20.84 \%)$ and $\mathrm{R}_{\mathrm{f}} 0.52$ (13.57\%) under white light of post derivatized plate. The TLC/HPTLC of successive hexane, chloroform, ethanol would reveal the presence of a number of phytoconstituents which are low polar, medium polar and high polar respectively (32-34).

\section{Conclusion}

The powder microscopic characters, TLC/HPTLC photos and fingerprint profiles are distinct to Rattha Piththathirku Kudinir Chooranam and the same could be applied for the quality control of the drug as pharmacopoeial reference standards. 


\section{Acknowledgements}

Authors are thankful to The Director-General, Central Council for Research in Siddha and The Assistant Director I/c, Siddha Central Research Institute, for facilities and support.

\section{Authors' contributions}

AKM, ST and RA carried out the physicochemical parameters and TLC/HPTLC studies. KGD and KNSK contributed to microscopic studies and RS designed the study, compilation, coordination and final proofing.

\section{Conflict of interests}

The authors declare no conflict of interest.

\section{Supplementary files}

Fig. 1. TLC/HPTLC of n-hexane extract of Rattha Piththathirku Kudinir Chooranam.

Fig. 2. TLC/HPTLC of chloroform extract of Rattha Piththathirku Kudinir Chooranam.

Fig. 3. TLC/HPTLC of ethanol extract of Rattha Piththathirku Kudinir Chooranam.

Fig. 4. TLC/HPTLC of hydro-alcohol extract of Rattha Piththathirku Kudinir Chooranam.

\section{References}

1. WHO Global Report: Preventing Chronic Diseases: A vital investment. Geneva: World Health Organization; 2005. Available from https://www.who.int/chp/chronic_disease report/en/

2. World Health Organization. Newsroom-Factsheet-DetailHypertension. 2019 September 13. Available from https://who.int/news-room/fact-sheets/detail/hypertension

3. Welz AN, Emberger-Klein A, Menrad K. Why people use herbal medicine: insights from a focus-group study in Germany. BMC

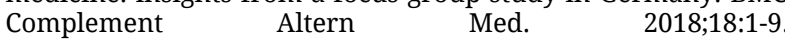
https://doi.org/10.1186/s12906-018-2160-6

4. WHO Global Report on Traditional and Complementary Medicine. Geneva: World Health Organization; 2019. p.10. Available from https://who.int/traditional-complementaryintegrative-medicine/WhoGlobalReportOnTraditionalAndCom plementary Medicine2019.pdf

5. Theraiyar Kudinir (Moolamum Uraiyam). 2nd ed, New Delhi: Central Council for Research in Ayurveda and Siddha; 1996. p.46.

6. Srishailam M, Kasala S, Veena P, Santosha D, Ramanjaneyulu $\mathrm{K}$, Himabindhu J. Investigation of phytochemical screening and in-vitro anthelmintic activity of Zaleya decandra (L). Int J Pharm Pharm Res. 2016;7(3):174-80.

7. Gajjala K, Anisetti R, DodlaJP, Rathod AK. Phytochemical investigation and cytotoxic activity of hydro alcoholic fraction of Trianthema decandra. Indian J Biotechnol. 2019;18:193-203. http://nopr.niscair.res.in/handle/123456789/53100

8. Global Biodiversity Information Facility. Occurrence-SpeciesDataset-Taxon. Available from https://www.gbif.org/occurrence/map?taxon_key=3703233

9. Kirtikar KR, Basu BD. Indian medicinal plants. 1st ed. Dehradun: International Book Distributors; 1991. p.1182.
10. Nadkarni AK. The Indian Materia Medica. 3rd ed, Bombay: Popular Prakasan; 1976. p.122.

11. Malarvizhi D, Anusooriya P, Meenakshi P, Sowmya S, Oirere E, Gopalakrishnan VK. Isolation, structural characterisation of oleic acid from Zaleya decandra root extract. Anal Chem Lett. 2016;6(5):669-77.

https://doi.org/10.1080/22297928.2016.1238319

12. Meenakshi P, Bhuvaneshwari R, Rathi MA, Thirumoorthi L, Guravaiah DC, Jiji MJ, Gopalakrishnan VK. Antidiabetic activity of ethanolic extract of Zaleya decandra in alloxan-induced diabetic rats. Appl Biochem Biotechnol. 2010;162:1153-59. https://doi.org/ 10.1007/s12010-009-8871-x

13. Balamurugan G, Muthusamy P. Observation of the hepatoprotective and antioxidant activities of Trianthema decandra Linn. (Vallaisharunnai) roots on carbon tetrachloride-treated rats. Bangladesh J Pharmacol. 2008;3:8389. https://doi.org/10.3329/bjp.v3i2.890

14. Awang DVC. Ginger. Can Pharm J. 1992;125:309-11.

15. Wang WH, Wang ZM. Studies of commonly used traditional medicine-ginger. Zhongguo Zhong Yao Za Zhi. 2005;30:1569-73. https://pubmed.ncbi.nlm.nih.gov/16422532/

16. Tapsell LC, Hemphill I, Cobiac L, Patch CS, Sullivan DR, Fenech $M$, et al.. Health benefits of herbs and spices: the past, the present, the future. Med J Aust. 2006;185(4):S4-S24. https://doi.org/ 10.5694/j.1326-5377.2006.tb00548.x

17. Khodaie L, Sadeghpoor O. Ginger from ancient times to the new outlook. Jundishapur J Nat Pharm Prod. 2015;10(1): e18402. $\quad$ https://www.ncbi.nlm.nih.gov/pmc/ articles/PMC4377061/

18. Liu Y, Liu J, Zhang Y. Research progress on chemical constituents of Zingiber officinale Roscoe. Biomed Res Int. 2019; 1-21. https://doi.org/10.1155/2019/5370823

19. Connwell DW, Sutherland MD. A re-examination of gingerol, shogaol and zingerone, the pungent principles of ginger (Zingiber officinale Roscoe). Aust J Chem. 1969;22:1033-43. https://doi.org/10.1071/CH9691033

20. Kikuzaki H, Tsai SM, Yoshiteru O. Gingerdiol related compounds from the rhizomes Zingiber officinale. Phytochemistry. 1992;32:1783-86. https://doi.org/10.1016/00319422(92)83147-Q

21. Vernin G Parkanyl C. "Chemistry of ginger," in Ginger: The Genus Zingiber, Ravindran PN and Nirmal Babu K, editors. New York: CRC Press; 2005. p.87-180.

22. Katsuya E, Emi K, Yoshiteru O. Structures of antifungal diarylheptenones, gingerenones $\mathrm{A}, \mathrm{B}, \mathrm{C}$ and isogingerenone $\mathrm{B}$, isolated from the rhizomes of Zingiber officinale Phytochemistry. 1990:29(3):797-99. https://doi.org/10.1016/0031-9422(90)80021-8

23. Kami T, Nakayama M, Hayashi S. Volatile constituents of Zingiber officinale. Phytochemistry. 1972;11:3377-81. https://doi.org/10.1016/S0031-9422(00)86412-2

24. Denyer $\mathrm{CV}$, Jackson P, Loakes DM. Isolation of anti-rhinoviral sesquiterpenes from ginger (Zingiber officinale). J Nat Prod. 1994;57:658-62. https://doi.org/10.1021/np50107a017

25. Ali BH, Blunden G, Tanira MO, Nemmar A. Some phytochemical, pharmacological and toxicological properties of ginger (Zingiber officinale Roscoe): A review of recent research. Food Chem Toxicol. 2008;46:409-20. https://doi.org/10.1016/j.fct.2007.09.085

26. Ghayur MN, Gilani AH. Ginger lowers blood pressure through blockade of voltage-dependent calcium channels. J Cardiovasc Pharmacol. 2005;45(1):74-80. https://doi.org/10.1097/00005344200501000-00013

27. Ahad A, Raish M, Bin Jardan YA, Alam MA, Al-Mohizea AM, AlJenoobi FI. Effect of Hibiscus sabdariffa and Zingiber officinale on the anti-hypertensive activity and pharmacokinetic of losartan in hypertensive rats. Xenobiotica. 2000;50(7):847-57. DOI $10.1080 / 00498254.2020 .1729446$. https://doi.org/10.1080/00498254.2020.1729446 
28. Anonymous. Quality control methods for medicinal plant materials. Geneva: World Health Organization; 1998.

29. Elankani P, Murugammal S, Shakila R, Pitchiahkumar M, Kabilan N. Chemical standardisation of thetran vithai kutinir chooranam - an antidiabetic Siddha polyherbal formulation. Pharmacog 2019;11(5):1106-13. https://doi.org/10.5530/pj.2019.11.173

30. Sivaranjani K, Shakila R, Manickavasakam K. Standardisation of Siddha polyherbal formulation parangipattai Chooranam. Int J Res Ayurveda Pharm. 2015;6(4):443-48. https://doi.org/10.7897/2277-4343.06485

31. Akila B, Manickavasakam K, Shakila R. Analytical study on siddha herbomineral formulation: Chandrakanthi Chooranam. Int J Pharm Bio Sci. 2014;5(4):175-85.

32. Sujith T, Shakila R, Mandal AK, Divya KG, Mahesh F, Sunilkumar KN, Ganesan R. Powder Microscopic, Physicochemical, HPTLC and Antioxidant Studies on Noccik Kudinir Chooranam - A Polyherbal Siddha Formulation. J Young Pharm. 2019;11(4):371-76 https://doi.org/10.5530/jyp.2019.11.76

33. Mandal AK, Shakila R, Thatipelli S, Rubeena M, Sunilkumar KN, Thilagam A, Ganesan R. Quality standards and antioxidant activity of Siddha formulation Cuvacakutori Chooranam. Int J Pharm Investig. https://doi.org/10.5330/ijpi.2019.3.24
34. Mandal AK, Shakila R, Divya KG, Rubeena M, Sunil Kumar KN, Sathiyarajeswaran P. Pharmacognostical-physico-chemical evaluation and development of HPTLC finger print for $\mathrm{Ci}$ chorium intybus L. fruits. Pharmacog J. 2017;10(4):695-700. https://doi.org/10.5530/pj.2018.4.115

Additional information

Peer review information: Plant Science Today thanks Sectional Editor and the other anonymous reviewers for their contribution to the peer review of this work.

Reprints and permissions information is available at

https://horizonepublishing.com/journals/index.php/PST/open_access_policy

Publisher's Note: Horizon e-Publishing Group remains neutral with regard to jurisdictional claims in published maps and institutional affiliations.

To cite this article: Mandal A K, Sujith T, Rajesh A, Divya KG, Sunilkumar KN, Shakila R. Powder microscopic, physicochemical and chromatographic approach for the quality control of anti-hypertensive drug Rattha Piththathirku Kudinir Chooranam. Plant Science Today. 2021;8(3):604-609. https://doi.org/10.14719/pst.2021.8.3.1137

Plant Science Today, published by Horizon e-Publishing Group, is covered by Scopus, Web of Science, BIOSIS Previews, Clarivate Analytics, etc. See https://horizonepublishing.com/journals/index.php/PST/indexing_abstracting 